\title{
URGENSI PENDIDIKAN MORAL DAN KARAKTER DALAM MEMBENTUK KEPRIBADIAN PESERTA DIDIK
}

\begin{abstract}
:
Oleh: Aprilina Wulandari ${ }^{1}$ Agus Fauzi ${ }^{2}$

Email:

1aprilinawulan11@gmail.com 2agusfauzie27@gmail.com

${ }^{1}$ UIN Maulana Malik Ibrahim, Malang ${ }^{2}$ STAI Al-Hikam, Malang

Character is an important thing in a person's life, because character is one of the determinants of a person's success. Therefore, a strong and positive character needs to be well formed. Education not only aims to make students smart, but also must be able to create noble values or character. Character building, especially students, is urgent and urgent to be realized in order to create a better society, namely a society that can face regional and global challenges. The regional and global challenge in question is how our young generation does not only have academic abilities that focus on cognitive abilities, but affective aspects and morality are also touched. The birth of moral and character education as an effort to revive the ideal-spiritual pedagogy that was lost by the wave of positivism. The substance of moral and character education is to form a complete personality for each student. The behaviors that are expected to be born are; do honesty, help people, respect, be responsible, appreciate, cherish, accept each other, sympathy, empatby, and accept what it is. Education as the totality of efforts and actions must be carried out through three educational institutions, namely, family, school and community. Therefore, it is necessary to integrate family education institutions, school education, and community education institutions in carrying out character education. The strengthening of the three educational institutions shows that character education is needed in order to anticipate future problems that are increasingly complex.
\end{abstract}

Keywords: Moral Education, Character Education, Student Personality

\section{PENDAHULUAN}

Pendidikan ialah usaha sadar secara teratur dan sistematis yang dilakukan oleh pendidik kepada peserta didik guna mempengaruhi peserta didik sehingga memiliki sifat dan karakter yang sesuai harapan dan citacita pendidikan. Oleh karena itu, pendidikan merupakan salah satu faktor yang paling penting dalam proses kehidupan insan. ${ }^{1}$ Pendidikan juga diartikan sebagai suatu proses pembelajaran yang meliputi pengetahuan, keterampilan, dan kebiasaan-kebiasaan yang diwariskan secara berkelanjutan dari generasi ke generasi. Upaya pewarisan tersebut dapat melalui pengajaran, pelatihan, dan penelitian. Hal tersebut dapat diterapkan di sekolah oleh pendidik kepada

\footnotetext{
${ }^{1}$ Djuwairiyah dan Moh. Nawafil, "Urgensi Pengelolaan Kelas: Suatu Analisis Filosofis dan Pemahaman Dasar Bagi Kalangan Pendidik di Pesantren", Edupedia: Jurnal Studi Pendidikan dan Pedagogi Islam, Vol. 5, No. 2, (Januari: 2021), 27.
}

peserta didik melalui proses pembelajaran yang baik tanpa mengesampingkan pendidikan karakternya.

Pembangunan pendidikan adalah upaya untuk mewujudkan tujuan nasional sebagaimana diamanatkan dalam Pembukaan Undang-Undang Dasar 1945 alinea-4 yaitu "memajukan kesejahteraan umum, mencerdaskan kehidupan bangsa, dan ikut melaksanakan ketertiban dunia”. Berpijak pada amanat tersebut, maka pendidikan merupakan hak setiap warga negara Indonesia untuk memperoleh pendidikan yang diselenggarakan melalui sistem pendidikan nasional. Tujuan pendidikan tersebut tampaknya masih jauh dari harapan masyarakat Indonesia. Sejak Indonesia merdeka, pelaksanaan pendidikan berjalan seadanya dan telah berhasil mencetak manusia intelektual, alim tapi kurang bermoral. 
Kenyataan menunjukkan bahwa bangsa Indonesia sedang mengalami krisis moral baik di tingkat penguasa maupun rakyat jelata (biasa). Pendidikan moral pada lembaga pendidikan sejak sekolah dasar hingga perguruan tinggi sudah diberikan dan diatur dalam kurikulum yang berlaku. Pendidikan moral yang diharapkan untuk membentuk karakter individu telah diajarkan pada semua kalangan baik kalangan pejabat tinggi negara (melalui Lemhanas), pegawai negeri (pada saat diklat prajabatan) sampai pada kegiatan organisasi kemasyarakatan, ternyata gagal membawa masyarakat kita ke arah yang lebih baik dalam hal membentuk karakter bangsa. Maraknya korupsi, kolusi, dan nepotisme $(\mathrm{KKN})$, kejahatan seksual, penggunaan obatobat terlarang dan kegiatan menyimpang lainnya bukan dilakukan oleh manusia yang tidak berpendidikan, akan tetapi sebagian besar pelakunya adalah mereka yang berpendidikan bahkan berpendidikan tinggi.

Penanaman pendidikan karakter di sekolah sangatlah penting demi mewujudkan generasi yang tidak hanya cerdas tetapi juga memiliki karakter yang baik. Karakter dalam hal ini diartikan sebagai cara berpikir maupun bertingkah laku yang menjadikan ciri khas seseorang untuk hidup, berinteraksi, dan bekerja sama, baik di lingkup keluarga, masyarakat, bangsa, dan negara. ${ }^{2}$ Pada hakikatnya, pembangunan karakter bangsa merupakan pembangunan moral bangsa itu sendiri. Pembangunan karakter bangsa perlu dimulai dari pembangunan masing-masing warga masyarakat. Apabila warga masyarakatnya memiliki moral yang baik, maka baiklah karakter bangsa dan jayalah suatu bangsa tersebut, begitupun sebaliknya.

\section{PEMBAHASAN}

\section{Konsep dan Urgensi Moral}

Secara etimologis kata moral berasal dari bahasa Latin yaitu mores. Mores berasal dari kata mos yang artinya tabiat, kesusilaan, atau kelakuan. Menurut Kohlber, moral ialah suatu nilai kebaikan manusia sebagai manusia. Dalam kebaikan moral terkandung nilai-nilai universal kemanusiaan. ${ }^{3}$

\footnotetext{
2 Agus Wibowo, Pendidikan Karakter: Metode Membangun Karakter Bangsa Berperadaban (Yogyakarta: Pustaka Pelajar, 2012), 33.

3 Hadi Machmud, "Urgensi Pendidikan Moral dalam Membentuk Kepribadian Anak," Jurnal Al-Ta'dib, Vol. 7, No. 2 (Juli: 2014), 77.
}

Terdapat beberapa istilah yang memiliki makna dekat dengan istilah moral, yaitu akhlak, budi pekerti, etika, dan nilai. Pertama, kata akhlak berasal dari bahasa Arab yang dapat diartikan sebagai budi pekerti atau menempatkan sesuatu sesuai dengan tempatnya. Akhlak pada hakikatnya mengajarkan tentang bagaimana manusia berhubungan dengan Tuhan dan dengan sesama manusia lainnya.

Kedua, budi pekerti berasal dari bahasa Sansekerta yang bermakna sama dengan tata krama. Menurut Ki Hajar Dewantara, pendidikan budi pekerti bertujuan agar anak dapat menyadari, merasakan, dan melakukan (ngerti, ngrasa, lan nglakoni) tindakan yang sesuai dengan norma-norma yang berlaku di masyarakat. Nilai-nilai budi pekerti yang harus diajarkan kepada anak antara lain bersih badan maupun pakaian yang dikenakan, menghormati orang lain, menolong sesama teman yang membutuhkan, bersikap sopan, dan dilarang berteriak-teriak agar tidak mengganggu orang lain. Ki Hajar Dewantara berpendapat bahwa isi dari pengajaran budi pekerti ialah moral (kesusilaan) yang meliputi adat serta hukum kesusilaan, sehingga budi pekerti sama dengan moral.

Ketiga, etika ialah suatu cabang filsafat yang membahas mengenai nilai dan norma yang menentukan seseorang di hidupnya. Bertens mendefinisikan etika ke dalam tiga makna. Pertama, etika diartikan sebagai nilai-nilai atau norma-norma yang menjadi pedoman manusia dalam mengatur perilakunya. Kedua, etika sebagai kumpulan dari nilai-nilai atau kode etik. Ketiga, etika ialah ilmu baik dan buruk.

Keempat, Nilai (value) merupakan suatu rujukan dan keyakinan dalam menentukan sebuah pilihan. Di dalam suatu nilai terdapat keyakinan, norma, tujuan, sifat, cara, serta ciriciri pola pikir, sikap, dan tingkah laku. ${ }^{4}$ Dengan demikian dapat dipahami bahwa istilah-istilah yang memiliki makna dekat dengan moral di atas sangat ditentukan oleh niat maupun iktikad dari lingkungan manusia.

Pendidikan moral secara terminologi lebih cenderung terhadap penyampaian nilai-nilai yang benar dan salah berdasarkan kebiasaan maupun

\footnotetext{
4 Hadi Machmud, "Urgensi Pendidikan Moral dalam Membentuk Kepribadian Anak," Jurnal Al-Ta'dib, Vol. 7, No. 2 (Juli: 2014), 77-78.
} 
adat yang berlaku di masyarakat pada umumnya. Pendidikan moral dapat diartikan sebagai ilmu yang mengajarkan tentang nilai-nilai kebaikan manusia.

Menurut Harderman, ada empat faktor yang berperan dalam perkembangan nalar moral antara lain: tingkat intelegensi, sikap orang tua, status sosial ekonomi, dan latar belakang kebudayaan. Sedangkan Clarizio dan Mc. Coy menyatakan ada tiga hal yang berpengaruh dalam perkembangan moral yaitu: cara pengasuhan anak, faktor kebudayaan dan tingkat intelegensi. Dari kedua pendapat tersebut terdapat kesamaan pandangan bahwa faktor intelegensi dan kebudayaan dapat mempengaruhi perkembangan moral. Sedangkan faktor lain seperti status sosial ekonomi orang tua, sikap orang tua, dan cara pengasuhan orang tua bukan berarti tidak berpengaruh dalam perkembangan moral, namun jika ditelaah secara lebih lanjut, faktorfaktor sosial ekonomi, sikap orang tua, dan cara mengasuh anak, sebenarnya telah tercakup dalam faktor kebudayaan.

\section{Konsep dan Urgensi Pendidikan Karakter}

Ki Hajar Dewantara mengungkapkan bahwasanya pendidikan merupakan daya upaya guna memajukan pertumbuhan nilai moral, pikiran dan tumbuh anak yang saling keterkaitan antara satu dengan yang lain agar dapat memajukan kesempurnaan hidup. ${ }^{5}$

Di dalam UU No. 20 Tahun 2003 tentang Sisdiknas disebutkan, "Pendidikan merupakan upaya sadar dan terencana dalam proses pembimbingan dan pembelajaran bagi individu agar tumbuh dan berkembang menjadi manusia yang mandiri, bertanggung jawab, kreatif, berilmu, sehat, dan berakhlak (berkarakter) mulia." Lebih lanjut harus diingat bahwa secara eksplisit pendidikan karakter atau (watak) adalah amanat Undang-Undang Nomor 23 Tahun 2003 tentang Sisdiknas (Sistem Pendidikan Nasional) menegaskan bahwa "Pendidikan Nasional berfungsi mengembangkan kemampuan dan membentuk watak serta peradaban bangsa yang bermartabat dalam rangka mencerdaskan kehidupan bangsa, bertujuan untuk berkembangnya potensi peserta didik agar menjadi manusia yang beriman dan bertakwa kepada Tuhan Yang Maha Esa, berakhlak mulia, sehat, berilmu, cakap, kreatif, mandiri, dan

\footnotetext{
${ }^{5}$ Zaim Elmubarok, Membumikan Pendidikan Nilai, (Bandung:
} Penerbit Alfabeta, 2019), 2. menjadi warga negara yang demokratis serta bertanggung jawab". ${ }^{6}$ Dengan adanya suatu proses pendidikan diharapkan dapat terbentuk pribadi manusia yang unggul.

Dilihat berdasarkan hukum yuridis yang telah disebutkan di atas, maka pendidikan nasional mengemban suatu misi untuk membangun manusia sempurna (insan kamil). Sehingga dibutuhkan suatu sistem pendidikan yang ditopang oleh pengelolaan serta pelaksanaan yang baik agar jati diri suatu bangsa dapat dibangun dengan utuh. Dengan demikian, pendidikan nasional harus bermutu dan berkarakter. $^{7}$

Secara etimologis, istilah karakter berasal dari bahasa Yunani charassein yang berarti "to engrave". Kata "to engrave" bisa diartikan mengukir, melukis, menggoreskan atau memahatkan. Istilah "karakter" dalam bahasa Inggris (character) juga memiliki arti yang sama yakni mengukir, melukis, menggoreskan atau memahatkan. ${ }^{8}$ Karakter juga dapat diartikan to mark (menandai) dan memfokuskan tentang bagaimana mengaplikasikan nilai kebaikan dalam tindakan. ${ }^{9}$

Sedangkan dalam Kamus Umum Bahasa Indonesia, karakter adalah tabiat, watak, sifatsifat kejiwaan, akhlak atau budi pekerti yang membedakan seseorang dengan yang lain. ${ }^{10} \mathrm{Hal}$ ini berarti bahwa orang yang berkarakter ialah orang yang berkepribadian, bersifat, berperilaku, bertabiat, atau berwatak tertentu sehingga hal tersebut menjadi ciri khas orang tersebut.

Secara terminologis, Griek dalam pendapatnya mengemukakan bahwasanya karakter merupakan paduan dari segala tabiat seseorang yang sifatnya tetap sehingga hal tersebut menjadi tanda khusus untuk membedakannya dengan orang lain. Sedangkan Damanik mengutip dari tulisan A. Sjiamsuri menyatakan bahwa karakter adalah gambaran

\footnotetext{
${ }^{6}$ Suyadi, Strategi Pembelajaran Pendidikan Karakter (Bandung: PT Remaja Rosdakarya, 2013), 4.

7 Suyadi, Strategi Pembelajaran Pendidikan Karakter (Bandung: PT Remaja Rosdakarya, 2013), 4-5.

${ }^{8}$ Zaim Elmubarok, Membumikan Pendidikan Nilai, (Bandung: Penerbit Alfabeta, 2019), 5.

${ }_{9}$ Tuhana Taufiq Andrianto, Mengembangkan Karakter Sukses Anak di Era Cyber (Yogyakarta: Ar-Ruzz Media, 2011), 17.

${ }_{10}$ Tuhana Taufiq Andrianto, Mengembangkan Karakter Sukses Anak di Era Cyber (Yogyakarta: Ar-Ruzz Media, 2011), $17-$ 18.
} 
siapa Anda sesungguhnya. ${ }^{11}$ Dengan demikian, karakter mengandung makna penggambaran dengan tujuan untuk mengenalkan suatu objek maupun subjek (orang) berdasarkan ciri atau tanda-tanda yang nampak pada dirinya.

Dari konsep pendidikan dan karakter tersebut, muncullah istilah pendidikan karakter. Beberapa pakar pendidikan mendefinisikan pendidikan karakter sebagai berikut:

1. Menurut T. Ramli: "Pendidikan karakter mempunyai esensi dan arti yang sama dengan pendidikan moral dan pendidikan akhlak dengan tujuan membentuk pribadi anak agar menjadi manusia yang baik, baik sebagai warga masyarakat maupun warga negara." Maka, pendidikan karakter yang terdapat dalam konteks pendidikan di Indonesia merupakan pendidikan yang berusaha membina kepribadian generasi muda. ${ }^{12}$

2. Menurut Lickona: "Pendidikan karakter mencakup tiga unsur pokok, yaitu mengetahui kebaikan, mencintai kebaikan, dan melakukan kebaikan." Dari konsep tersebut dapat diartikan bahwa pendidikan karakter merupakan upaya sadar dan terencana dalam mengetahui kebenaran atau kebaikan, mencintainya serta melakukannya di kehidupan sehari-hari. ${ }^{13}$

3. Pendidikan karakter merupakan suatu sistem penanaman nilai-nilai pendidikan karakter yang ditujukan terhadap warga sekolah dengan melibatkan beberapa komponen meliputi pengetahuan, kemauan atau kesadaran, dan tindakan untuk melaksanakan nilai-nilai tersebut. ${ }^{14}$

4. Pendidikan karakter merupakan dinamika serta pengembangan kemampuan secara berkesinambungan yang terdapat dalam diri manusia untuk menginternalisasi nilai sehingga dapat menghasilkan disposisi aktif dan stabil pada diri individu. ${ }^{15}$

5. Pendidikan karakter adalah pendidikan budi pekerti plus yang merupakan suatu program pengajaran di sekolah dengan tujuan mengembangkan tabiat dan watak peserta didik dengan cara menghayati nilai-nilai dan

11 Tuhana Taufiq Andrianto, Mengembangkan Karakter Sukses Anak di Era Cyber (Yogyakarta: Ar-Ruzz Media, 2011), $17-$ 19.

${ }^{12}$ Hamdani Hamid dan Beni Ahmadi Saebani, Pendidikan Karakter Perspektif Islam (Bandung: CV Pustaka Setia, 2013), 33-34.

${ }^{13}$ Suyadi, Strategi Pembelajaran Pendidikan Karakter (Bandung: PT Remaja Rosdakarya, 2013), 6.

${ }^{14}$ Hamid dan Saebani, Pendidikan Karakter Perspektif Islam, 33.

${ }^{15}$ Hamid dan Saebani, Pendidikan Karakter Perspektif Islam, 34. keyakinan masyarakat sebagai kekuatan moral dalam hidupnya melalui kejujuran, disiplin, dapat dipercaya, kerja sama yang menekankan ranah afektif tanpa meninggalkan ranah kognitif dan skill. ${ }^{16}$

Pendidikan karakter merupakan upaya sadar dan terencana guna mewujudkan kualitas kemanusiaan yang baik, baik untuk individu maupun masyarakat. Pendidikan karakter juga dapat dikatakan sebagai suatu usaha menanamkan nilai-nilai karakter pada peserta didik agar peserta didik senantiasa berpikir dan berpegang teguh pada prinsip-prinsip moral dalam hidupnya.

Pendidikan karakter memiliki makna yang lebih tinggi dibandingkan pendidikan moral. Hal ini dikarenakan pendidikan karekter tidak hanya mengajarkan tentang benar dan salah, tetapi juga menanamkan kebiasaan tentang hal-hal yang baik kepada peserta didik sehingga peserta didik mampu merasakan dan mau melaksanakan hal baik tersebut.

Adapun tujuan dari pendidikan karakter menurut Kemendikbud yaitu: "mengembangkan potensi kalbu/nurani/afektif peserta didik sebagai manusia dan warga negara yang memiliki nilai-nilai budaya dan karakter bangsa; mengembangkan kebiasaan dan perilaku peserta didik yang terpuji dan sejalan dengan nilai-nilai universal dan tradisi budaya bangsa yang religius; menanamkan jiwa kepemimpinan dan tanggung jawab peserta didik sebagai generasi penerus bangsa; mengembangkan kemampuan peserta didik untuk menjadi manusia yang mandiri, kreatif, dan berwawasan kebangsaan; mengembangkan lingkungan kehidupan sekolah sebagai lingkungan belajar yang aman, jujur, penuh kreativitas dan persahabatan."

Diselenggarakannya pendidikan karakter juga bertujuan untuk membentuk manusia agar berakhlak mulia dan bermoral baik sehingga kehidupan dan perkembangannya dapat dijaga dan dipelihara. ${ }^{18}$ Serta guna memperbaiki mutu pelaksanaan dan hasil pendidikan yang mengarah

\footnotetext{
16 Zubaedi, Desain Pendidikan Karakter (Jakarta: Kencana Prenada Media Grup, 2012), 25.

17 Agus Zaenul Fitri, Pendidikan Karakter Berbasis Nilai \& Etika di Sekolah (Yogyakarta: Ar-Ruzz Media, 2012), 24.

${ }^{18}$ Maksudin, Pendidikan Karakter Non-Dikotomik (Yogyakarta:
} Pustaka Pelajar, 2013), 58. 
pada pembentukan akhlak dan karakter peserta didik secara utuh, seimbang, dan terpadu. ${ }^{19}$

Berdasarkan Kemendiknas nilai-nilai pendidikan karakter meliputi: religius, jujur, toleransi, disiplin, kerja keras, kreatif, mandiri, demokratis, rasa ingin tahu, semangat kebangsaan, cinta tanah air, menghargai prestasi, komunikatif, cinta damai, gemar membaca, peduli lingkungan, peduli sosial, dan tanggung jawab. $^{20}$

Kemendiknas mengelompokkan nilai karakter yang harus dimiliki oleh peserta didik, yaitu:

1. Nilai karakter dalam hubungan manusia dengan Tuhan yaitu: religiutas

2. Nilai karakter dalam hubungan dengan diri sendiri, meliputi: kejujuran, kebersihan, dan kesehatan, kecerdasan, kedisiplinan, rasa tanggung jawab, berfikir logis, kritis, kreatif, inovatif, keingintahuan, ketangguhan cinta ilmu, jiwa kepemimpinan, rasa percaya diri, kerja keras, kemandirian, berorientasi pada tindakan, dan keberanian mengambil resiko

3. Nilai karakter dalam hubungan manusia dengan lingkungan, meliputi: kepedulian terhadap lingkungan

4. Nilai karakter dalam hubungan antar manusia, meliputi: tolong menolong, kesadaran akan hak dan kewajiban diri dan orang lain, kepatuhan pada aturan sosial, menghargai karya dan prestasi orang lain, demokrasi dan kesantunan.

5. Nilai berbangsa dan bernegara yang meliputi: nasionalisme dan menghargai keberagaman.

Apabila pendidikan gagal menanamkan nilai-nilai pada diri peserta didik sebagaimana dikemukakan di atas, maka yang akan terjadi adalah perpecahan dan perbedaan serta akan memudarkan nilai-nilai kebangsaan dan akan berdampak pada hilangnya karakter bangsa. Kegagalan pendidikan dalam membangun karakter peserta didik dapat terjadi apabila komponen dalam pendidikan (pendidik, peserta didik, kurikulum, sarana prasarana maupun lingkungan masyarakat) tidak dikelola dengan maksimal. Keseriusan pemerintah dalam mengelola semua komponen pendidikan perlu dibuktikan dengan aksi nyata yaitu dengan

\footnotetext{
${ }^{19}$ Masnur Muslich, Pendidikan Karakter: Menjawab Tantangan Krisis Multidimensial (Jakarta: Bumi Aksara, 2014), 81.

${ }^{20}$ Suyadi, Strategi Pembelajaran Pendidikan Karakter (Bandung: PT Remaja Rosdakarya, 2013), 7-9.
}

memberikan angaran pendidikan yang memadai, meningkatkan kesejateraan pendidik serta memberikan pengelolaan pendidikan kepada yang ahli di bidangnya dalam artian pendidikan jangan dijadikan sebagai komuditas kepentingan politik.

Pentingnya pendidikan karakter bagi peserta didik ialah mengembangkan diri peserta didik agar mampu tumbuh dan berkembang bersama nilai-nilai yang terkait dengan Tuhan Yang Maha Esa, diri sendiri, sesama manusia, dan lingkungan masyarakat. ${ }^{21}$

\section{Pembentukan Kepribadian Peserta Didik}

Kepribadian (personality) sering diartikan sebagai ciri yang menonjol yang terdapat pada diri seseorang yang menimbulkan kesan bagi orang lain terhadapnya. Kepribadian merupakan aspek penting yang membedakan manusia satu dengan lainnya. ${ }^{22}$

Murray berpendapat bahwa: "kepribadian sebagai kesinambungan bentuk-bentuk dan kekuatan fungsional yang dinyatakan lewat urutan-urutan dari proses yang terorganisir serta tingkah laku dari lahir sampai mati. Kepribadian merupakan unsur-unsur tingkah laku yang bersifat menetap dan berulang ataupun unsurunsur yang baru dan unik." Sedangkan menurut Jung, kepribadian ialah suatu sistem yang kompleks dari jaringan interaksi yang terjalin secara harmonis antara diri seseorang dan lingkungannya. ${ }^{23}$

Pembentukan kepribadian pada anak tidak terlepas dari bagaimana proses pendidikan yang diterapkan oleh orang tua dan orang-orang yang bertanggung jawab atas keberlangusungan hidup seorang anak. Pembentukan kepribadian dilakukan agar karakteristik psikologis seseorang yang berkaitan dengan kecendrungan untuk berhubungan sosial dengan orang lain, khususnya yang terkait dengan; pengendalian diri, keramahan, kegembiraan, keaktifan, dan kegairahan. Pendidikan menjadi salah satu faktor yang starategis dalam penanaman nilai-nilai, norma-norma, kemandirian, tanggung jawab,

\footnotetext{
${ }^{21}$ Akhmad Muhaimin Azzet, Urgensi Pendidikan Karakter di Indonesia (Yogyakarta: Ar-Ruzz Media, 2011), 88.

22 Hadi Machmud, "Urgensi Pendidikan Moral dalam Membentuk Kepribadian Anak," Jurnal Al-Ta'dib, Vol. 7, No. 2 (Juli: 2014), 79.

23 Hadi Machmud, "Urgensi Pendidikan Moral dalam Membentuk Kepribadian Anak," Jurnal Al-Ta'dib, Vol. 7, No. 2 (Juli: 2014), 78-79.
} 
serta pembentukan karakter atau kepribadian anak. Masing-masing dari pola tersebut memiliki ciri khas tersendiri, ada yang mengasuh dengan gaya pengasuhan demokratis yakni memberikan kebebasan untuk memilih dan melakukan suatu tindakan, bersifat hangat; ada yang menunjukkan kasih sayang yang mendalam, terbuka, saling menghormati, kerja sama, saling mempercayai, bertanggung jawab bersama; dan ada yang memiliki sikap responsif pada kebutuhan anak dan mendorongnya untuk mengungkapkan keinginan dan pendapat. ${ }^{24}$

Pendidikan berkaitan dengan karakteristik setiap individu dan inilah yang sekaligus membedakan dalam berbagai bidang seperti bidang akademik, sosial, kepribadian atau keterampilan lain, yang menjadikan anak memiliki sesuatu yang bernilai tinggi dan akan mengembangkan kepribadiannya. Seorang anak yang diasuh secara demokratis akan mengembangkan kepribadian rasa percaya diri, dapat bekerja sama, bersosialisasi, empati, menghargai orang lain, terbuka, dan bertanggung jawab. Sebaliknya anak yang diasuh dengan pola asuh permisif akan mengembangkan kepribadiannya lebih egois, cuek, sering ingin mau menang sendiri, dan berharap semua keinginannya akan terpenuhi. Kurang mampu bersosialisasi, menyesuaikan diri, selalu merasa gelisah atau berperasaan tidak menentu, menggunakan banyak mekanisme pembelaan diri.

Karakteristik yang dimiliki jika dididik dan diasuh secara demokrasi maka akan lebih efektif, baik secara sosial maupun dalam perolehan keterampilan sosial seperti kerjasama, prososial, berempati, kontrol diri, rasa mencintai, menyayangi, menghormati, menghargai, membedakan hak, kewajiban, benar dan salah, yang pada gilirannya akan menjadi anak menjadi manusia yang memiliki perilaku, moral dan kepribadian yang karimah.

\section{Pendidikan Moral dan Karakter Membentuk Kepribadian Peserta Didik}

Upaya dalam pembentukan kepribadian dapat dilakukan menggunakan berbagai metode dan pendekatan. Metode adalah cara atau kiatkiat yang dilakukan untuk mencapai sesuatu yang diinginkan. Pencapaian suatu tujuan tentunya memerlukan metode yang tepat dan cepat, atau

\footnotetext{
24 Hadi Machmud, "Urgensi Pendidikan Moral dalam Membentuk Kepribadian Anak," Jurnal Al-Ta'dib, Vol. 7, No. 2 (Juli: 2014), 80
}

efektif dan efisien. Metode dalam membentuk kepribadian peserta didik melalui pendidikan moral dan karakter dapat dilakukan dengan berbagai sikap, seperti: keteladanan; penanaman atau penegakan kedisiplinan; pembiasaan; menciptakan suasana kondusif; integrasi dan internalisasi. ${ }^{25}$

Keteladanan

Keteladanan memiliki pengaruh besar terhadap pembentukan karakter seseorang. Keteladanan lebih mengedepankan aspek tingkah laku berupa tindakan nyata yang tidak hanya anjuran semata. Terdapat dua model peneladanan dalam pendidikan karakter, yaitu: guru sebagai teladan dan kisah-kisah teladan. Terkait dengan pendidikan di sekolah, seorang guru (pendidi) harus memberikan contoh yang baik kepada peserta didik, baik dalam perkataan maupun perbuatan.

\section{Penanaman atau Penegakan Disiplin}

Pada hakikatnya, disiplin adalah suatu bentuk ketaatan yang sungguh-sungguh atas dasar kesadaran penuh dalam menjalankan tugas kewajiban dan berperilaku sesuai aturan yang berlaku dalam suatu lingkungan tertentu. Kedisiplinan adalah alat dalam mendidik karakter. Kurangnya kedisiplinan dapat berdampak pada melemahnya motivasi seseorang dalam melakukan sesuatu. Upaya yang dapat dilakukan dalam menegakkan kedisiplinan di antaranya: peningkatan motivasi; pendidikan dan latihan; kepemimpinan; penegakan aturan; penerapan reward dan punishment.

Motivasi adalah latar belakang yang mendorong atau menggerakkan seseorang melakukan sesuatu. Terdapat dua macam motivasi, yaitu ekstrinsik (dari luar diri individu) dan intrinsik (dari dalam diri individu). Penegakan disiplin bisa berawal dari motivasi ekstrinsik dengan paksaan atau pengaruh dari orang lain. Akan tetapi, seiring berjalannya proses tersebut dapat berubah ke arah motivasi intrinsik. Hal tersebut bisa terjadi setelah merasakan adanya dampak positif bagi dirinya yang kemudian orang tersebut akan menjalankan segala sesuatunya atas dasar kesadaran diri.

Pendidikan dan latihan adalah salah satu faktor penting guna menempa disiplin. Keduanya adalah proses yang di dalamnya terdapat aturan-aturan maupun prosedur-

\footnotetext{
${ }^{25}$ M. Furqon Hidayatullah, Pendidikan Karakter: Membangun Peradaban Bangsa (Surakarta: Yuma Pustaka, 2010), 39-55.
} 
prosedur yang wajib diikuti oleh peserta didik. Misalnya, mematuhi peraturan yang berlaku, mendidik peserta didik untuk membiasakan hidup berkelompok, kerja sama yang baik, menumbuhkan rasa setia kawan, dan sebagainya. Peraturan-peraturan tersebut sebagai faktorfaktor penting yang turut andil dalam tercapainya suatu tujuan.

Faktor keteladanan yang juga sangat berpengaruh dalam pembinaan disiplin adalah pemimpin. Kualitas kepemimpinan dari seorang pemimpin terhadap anggota yang dipimpinnya akan menentukan keberhasilan dalam pembinaan disiplin.

Penegakan disiplin biasanya berhubungan erat dengan penerapan aturan. Idealnya ketika menegakkan aturan hendaknya lebih diarahkan pada "takut terhadap aturan bukan takut terhadap orang". Orang hendaknya menjalankan sesuatu karena taat terhadap aturan yang berlaku bukan karena taat terhadap orang yang memberi aturan atau yang memerintah. Jika hal tersebut tumbuh dari kesadaran masing-masing individu, maka terciptalah kondisi yang aman dan nyaman. Pada hakikatnya, penegakan disiplin adalah mendidik supaya seseorang mentaati peraturan yang berlaku.

Dalam rangka penegakan kedisiplinan, reward and punishment atau penghargaan dan hukuman adalah dua kesatuan yang tidak bisa terpisahkan. Keduanya harus berjalan efektif.

\section{Pembiasaan}

Terbentuknaya suatu karakter tidak bisa secara instan. Hal ini memerlukan waktu yang lama dan proses secara terus-menerus. Kegiatan pembiasaan bisa berjalan secara spontan, misalnya saling menghormati, saling menyapa, dan berbuat baik antar sesama. Pembiasaan diarahkan pada aktivitas tertentu dalam upaya pembudayaan sehingga menjadi aktivitas yang tersistem.

\section{Menciptakan Suasana Kondusif}

Menciptakan suasana yang kondusif menjadi salah satu upaya membangun budaya yang memungkinkan terbentuknya suatu karakter.

\section{Integrasi dan Internalisasi}

Dalam pelaksanaanya, pendidikan karakter sebaiknya diterapkan secara terintegrasi dan terinternalisasi ke dalam segala aspek kehidupan.
Maksud dari terintegrasi karena pada dasarnya pendidikan karakter merupakan landasan dari seluruh aspek sehingga tidak dapat dipisahkan dengan aspek lain. Sedangkan terinternalisasi karena pendidikan karakter sangat penting guna mewarnai seluruh aspek kehidupan.

\section{Penanaman Karakter melalui Tripusat Pendidikan}

Nilai-nilai dan semangat yang terkandung dalam Pancasila dan Bhineka Tunggal Ika dapat menjadi inspirasi bagi penguatan identitas pendidikan karakter bangsa dalam menghadapi krisis multidimensi. Pendidikan sebagai totalitas usaha dan tindakan harus dijalankan melalui tiga lembaga pendidikan yaitu, keluarga, sekolah dan masyarakat. Oleh karena itu, diperlukan keterpaduan lembaga pendidikan keluarga, pendidikan sekolah dan lembaga pendidikan masyarakat dalam menyelenggarakan pendidikan karakter.

\section{Lembaga Pendidikan Keluarga}

Pendidikan karakter dimulai dari lingkungan keluarga. Pendidikan yang diberikan dalam lingkungan keluarga yang mempersiapkan suatu model mendidik untuk membentuk kecakapan hidup sebagai dasar dalam kehidupan selanjutnya. Apabila pendidikan kecakapan hidup sudah tertanam pada pendidikan keluarga maka tidak sulit untuk mengembangkannya di lingkuan sekolah.

Peranan keluarga sebagai lingkungan sosial pertama, memiliki hubungan dengan kepribadian anak. Keluarga sebagai pintu pertama dan utama yang dilalui individu merupakan sarana awal dan pokok dalam membentuk kepribadian dan karakter. Di dalam keluarga seseorang dapat hidup bersama dengan sekelompok orang secara akrab. Karena salah satu fungsi keluarga adalah merawat, melatih anak, menjaga dan mendidik anak-anak secara mental spritual. Pendidikan karakter dan nilainilai keperibadian menjadi tujuan utama pendidikan kaluarga.

Pendidikan keluarga diposisikan sebagai lembaga pembentukan kecerdasan spiritual. Dalam keluarga benih pendidikan mulai tumbuh dalam hubungan cinta kasih, tolong menolong, dan saling memberi pengertian. Keluarga merupakan lembaga pendidikan permulaan sehingga orang tua (ayah dan ibu) pertama kalinya berstatus sebagai panutan (guru) untuk 
memberikan pendidikan budi pekerti, nilai kebaikan dan nilai etika.

Pada dasarnya keluarga berkewajiban meletakkan dasar kependidikan berupa potensi nilai kemanusiaan. Potensi kecerdasan spiritual menjadi tumbuh dan berkembang apabila dirawat dan dijabarkan dalam kehidupan seharihari oleh keluarga (orang tua). Tiga moral spiritual yang dikembangkan dalam keluarga adalah syukur, sabar, dan ikhlas sebagai benteng dalam upaya membangun kecerdasan spiritual dalam rangka menanamkan nilai-nilai moral kepada anak. ${ }^{26}$

Dengan demikian dapat dipahami bahwa keluarga sebagai sistem sosial merupakan faktor determinan pertama dan utama dalam memberikan pendidikan kepribadian, budi pekerti, dan karakter dalam rangka pembentukan pondasi watak terutama pada anak berumur di bawah lima tahun, sehingga di atas pondasi itulah sifat-sifat kepribadaian anak yang diperolehnya melalui proses inkulturasi dan sosialisasi di lingkungan keluarga sangat menentukan pula terhadap pembentukan dan perkembangan kecerdasan moral emosional anak.

\section{Lembaga Pendidikan Sekolah}

Pendidikan sekolah merupakan lembaga pendidikan kedua setelah pendidikan keluarga. Pada lembaga pendidikan formal (sekolah) inilah peran guru sebagai pemeran utama pendidikan di sekolah sangatlah menetukan. Hal ini sejalan dengan Peraturan Pemerintah No. 74 Tahun 2008 tentang Guru Pasal 1 ayat (1) dijelaskan bahwa: "guru adalah pendidik profesional dengan tugas utama mendidik, mengajar, membimbing, mengarahkan, melatih, menilai, dan mengevaluasi peserta didik pada pendidikan anak usia dini jalur pendidikan formal, pendidikan dasar, dan pendidikan menengah.”27

\footnotetext{
26 Sirajuddin Saleh, "Peran Lembaga Pendidikan Dalam Membentuk Karakter Bangsa," Seminar Nasional: Pendidikan Ilmu-Imu Sosial Membentuk Karakter Bangsa Dalam Rangka Daya Saing Global, Kerjasama: Fakultas Ilmu Sosial UIN Makassar dan Himpunan Sarjana Pendidikan Ilmu-Ilmu Sosial Indonesia, Oktober 2016, 108.

27 Sirajuddin Saleh, "Peran Lembaga Pendidikan Dalam Membentuk Karakter Bangsa," Seminar Nasional: Pendidikan Ilmu-Imu Sosial Membentuk Karakter Bangsa Dalam Rangka Daya Saing Global, Kerjasama: Fakultas Ilmu Sosial UIN Makassar dan Himpunan Sarjana Pendidikan Ilmu-Ilmu Sosial Indonesia, Oktober 2016, 108-109.
}

Hal ini berarti kualitas manusia yang dibutuhkan oleh bangsa Indonesia pada masa depan adalah mampu menghadapi persaingan yang semakin ketat dengan bangsa lain di dunia. Kualitas manusia Indonesia tersebut dihasilkan melalui penyelenggaraan pendidikan yang bermutu oleh pendidik profesional. Oleh karena itu, guru sebagai pendidik profesional mempunyai fungsi, peran, dan kedudukan yang sangat strategis. Guru sebagai tenaga profesional mempunyai visi terwujudnya penyelenggaraan pembelajaran sesuai dengan prinsip-prinsip profesionalitas.

Pendidikan sekolah berlangsung dalam institusi persekolahan dengan waktu, materi serta tempat yang diatur sedemikian rupa sehingga disebut sebagai pendidikan formal. Tujuan pendidikan sekolah adalah mengembangkan dan membentuk potensi intelektual atau pikiran menjadi cerdas. Pencerdasan pikiran (intelektual) tersebut dilakukan dengan meningkatkan pengetahuan mengenai membaca, menulis, dan menghitung. Walaupun di samping itu, penanaman nilai karakter juga perlu ditanamkan kepada peserta didik setiap harinya. Sebab karakter ialah representasi dari baik-buruknya seseorang. 28

Pada lembaga pendidika sekolah, guru sangat berperan untuk menjadi contoh sekaligus motivator dan inspirator sehingga peserta didik akan lebih tertarik dan antusias dalam belajar, sehingga hasil belajar yang didapat berdaya guna dan berhasil. Guru merupakan sosok yang harus digugu dan ditiru (teladan) bagi anak didiknya. Sebagai teladan tidaklah mudah bagi seorang guru karena setiap anak mengharapkan guru mereka dapat menjadi contoh atau model baginya. Oleh karena itu tingkah laku pendidik harus sesuai dengan norma-norma yang dianut oleh masyarakat, bangsa dan negara. Karena nilai nilai dasar negara dan bangsa Indonesia adalah Pancasila, maka karakter yang tercermin pada tingkah laku pendidik harus selalu tercermin nilai-nilai Pancasila.

Guru sebagaimana orang tua sudah seharusnya menampilkan perilaku keseharian yang dapat menjadi tauladan bagi anak-anak didik. Guru bisa menjadi figur sentral dalam pembentukan kepribadian anak. Banyak anak

\footnotetext{
${ }^{28}$ Moh. Nawafil dan Hafifuddin Nur, "Pendidikan Indigenous Ala Pesantren Untuk Memperkokoh Karakter Generasi Milenial”, Edupedia: Jurnal Studi Pendidikan dan Pedagogi Islam, Vol. 5, No. 1, (Juli: 2020), 17.
} 
yang lebih cenderung untuk menjadikan tontonan sebagai model. Bisa saja hal ini terjadi karena orang tua yang mestinya bisa sebagai model jarang ditemui karena sibuk. Sehingga anak-anak mencari figur lainnya. Misalnya saja model itu bisa ditemukan pada diri pembantu, pada tokoh sinetron yang dikagumi, atau mungkin sahabatnya yang dijadikan figur. Di sinilah guru dituntut untuk menjadi model. Berikan yang terbaik buat anak-anak kita. Banyak anak-anak yang sukses karena melihat figur gurunya yang bersahaja, tegas, dan berwibawa.

Kemampuan intelektual dalam aspek membaca, menulis dan menghitung yang diajarkan oleh pendidik di sekolah perlu dipadukan dengan pembentukan kecerdasan moral emosional. Membaca (kecerdasan intelektual) ditanamkan pada diri anak bukan hanya sekedar membaca tulisan akan tetapi lebih dari pada itu ialah penanaman nilai-nilai membaca fakta kehidupan yang sedang berjalan atau belajar (Kecerdasan emosional). Sedangkan kemampuan menulis yang dimaksud dalam hal ini adalah selain mampu menulis lambinglambang (huruf dan angka) juga diharapkan mampu menulis segala gejala kehidupan sosial yang dialami atau diamati. Kemampuan menghitung bukan hanya dituntut untuk menghitung angka-angka, akan tetapi pendidikan sekolah dituntut untuk mengajarkan kepada anak didiknya menghitung atau membuat perhitungan agar setiap langkah kehidupan dapat menghasilkan kepastian.

Pendidikan sekolah dituntut untuk mampu mengembangkan berbagai potensi yang dibawa peserta didik dari pendidikan keluarga. Lembaga pendidikan sekolah bertanggung jawab atas kepercayaan keluarga atau masyarakat dalam hal pembinaan potensi akademik (inteltual) anak. Selain itu pendidikan sekolah diharapkan mampu mempersiapkan peserta didik untuk memiliki kemampuan dalam menjaga dan mengembangkan terbentuknya kreativitas (kecerdasan intelektual) dan sikap (kecerdasan moral) sebagai bagian dari pencerdasan moral emosional.

\section{Lembaga Pendidikan Masyarakat}

Pendidikan karakter bangsa harus segera dilaksanakan di semua jenjang pendidikan dari tingkat dasar sampai pendidikan tinggi yang diintegrasikan ke dalam setiap mata pelajaran/mata kuliah. Pendidikan karakter bangsa menjadi tanggung jawab setiap pendidik dalam melaksanakan proses pembelajaran, baik kurikuler maupun ekstra kurikuler dengan melalui keteladanan baik dalam bersikap, berperilaku, maupun berbahasa. 29

Selain itu sebagai warga masyarakat, peserta didik lebih banyak menghabiskan waktunya di tengah-tengah masyarakat. Oleh karena itu masyarakat dituntut untuk turut serta dalam pembentukan karakter anak. Pendidikan masyarakat merupakan pendidikan yang diselenggarakan dalam lingkungan masyarakat. Dalam sistem pendidikan nasional dikenal dua jalur pendidikan yaitu jalur pendidikan sekolah dan jalur pendidikan luar sekolah. Jalur pendidikan luar sekolah inilah yang sering disebut pendidikan masyarakat. Pendidikan luar sekolah (masyarakat) merupakan pendidikan yang bersifat kemasyarakatan yang diselenggarakan di luar sekolah melalui kegiatan belajar mengajar yang tidak berjenjang dan tidak berkesinambungan seperti kepramukaan, kursus, pendidikan keagamaan, dan lain-lain.

Selain itu dalam konteks kehidupan masyarakat pendidikan merupakan bagian dari upaya pencerdasan moral emosional yang akan membetuk karakter anak didik. Tanggung jawab masyarakat dalam penanaman kecerdasan moral emosional, spiritual dan intelektual sama kedudukannya dengan tanggung jawab keluarga (orang tua) dan guru (pendidik di sekolah). Pendidikan masyarakat bertanggung jawab terhadap penanaman nilai kebaikan untuk kemudian dapat menumbuhkembangkan keadilan dalam seluruh aspek sosial.

Pendidikan masyarakat diselenggarakan dengan pertimbangan bahwa luaran pendidikan sekolah dipandang belum sepenuhnya mampu memenuhi permintaan dinamika masyarakat khususnya dalam aspek keterampilan. Sedangkan dari aspek kecerdasan emosional, masyarakat dalam konteks sosial seluas-luasnya bertanggung jawab untuk pelanjut pendidikan keluarga dan pendidikan sekolah. Karena itu pendidikan masyarakat sering disebut sebagai pendidikan lapisan ketiga. Pendidikan karakter bangsa adalah suatu sistem pembentukan nilai-nilai karakter bangsa kepada warga masyarakat yang meliputi

\footnotetext{
29 Sirajuddin Saleh, "Peran Lembaga Pendidikan Dalam Membentuk Karakter Bangsa," Seminar Nasional: Pendidikan Ilmu-Ilmu Sosial Membentuk Karakter Bangsa Dalam Rangka Daya Saing Global, Kerjasama: Fakultas Ilmu Sosial UIN Makassar dan Himpunan Sarjana Pendidikan Ilmu-Ilmu Sosial Indonesia, Oktober 2016, 110.
} 
komponen pengetahuan, kesadaran atau kemauan, dan tindakan untuk melaksanakan nilai-nilai tersebut. Pendidikan karakter bangsa juga harus tergambar secara terpadu dalam semua komponen masyarakat. Selain itu, pendidikan karakter bangsa di lingkungan masyarakat harus dimaknai sebagai gambaran perilaku warga masyarakat dalam kesehariannya. Artinya seluruh lini dan komponen di lingkungan masyarakat hendaknya mencerminkan terwujudnya pendidikan karakter itu sendiri. Baik dalam bentuk materi maupun aplikasi di kehidupan mereka.

Pengembangan pendidikan karakter di lembaga pendidikan masyarakat seperti pendidikan keagamaan, juga berhubungan dengan pengembangan akhlak, moral dan pengembangan agama serta nilai spiritualitas seseorang.

Program pembentukan perilaku merupakan kegiatan yang harus dilakukan secara terus menerus dalam kehidupan sehari-hari peserta didik. Dengan kegiatan yang diterapkan secara terus menerus tersebut diharapkan anak dapat melakukan kebiasaan-kebiasaan yang baik. Pembentukan perilaku melalui pembiasaan yang dimaksud meliputi pembentukan moral agama, perasaan/emosi, kemampuan bermasyarakat dan disiplin. 30

Tujuan dari pembentukan perilaku adalah untuk mempersiapkan anak sedini mungkin dalam mengembangkan sikap dan perilaku yang didasari oleh nilai-nilai moral agama dan normanorma yang berlaku dalam masyarakat.31 Pengembangan dan pendidikan moral dalam membentuk kepribadian seseorang bertujuan untuk: melatih hidup tertib dan teratur; melatih sosialisasi; menanamkan toleransi dan sikap tenggang rasa; merangsang keberanian, tanggung jawab, sikap bangga dan bersyukur; melatih pengendalian emosi; melatih seseorang agar mampu menjaga dirinya sendiri; serta menanamkan sikap simpati, empati, gotong royong, menerima, dan menghargai.32

30 Hadi Machmud, "Urgensi Pendidikan Moral dalam Membentuk Kepribadian Anak," Jurnal Al-Ta'dib, Vol. 7, No. 2 (Juli: 2014), 81.

${ }^{31}$ Moh. Nawafil, Cornerstone of Education: Landasan-Landasan Pendidikan, (Yogyakarta: Absolute Media, 2018), 16.

32 Moh. Nawafil, Cornerstone of Education: Landasan-Landasan Pendidikan, (Yogyakarta: Absolute Media, 2018), 18-19.
Kompetensi yang ingin dicapai pada aspek pengembangan moral dan nilai-nilai agama adalah kemampuan melakukan ajaran agama, ibadah, mengenal dan percaya akan ciptaan Tuhan dan mencintai sesama.

\section{SIMPULAN}

Pendidikan moral merupakan hal sangat fundamen oleh karenanya sangat urgen ditanamkan pada peserta didik. Mengembangankan nilai dan sikap peserta didik dapat dipergunakan berbagai metode yang memungkinkan terbentuknya kebiasaankebiasaan yang didasari oleh nilai-nilai agama dan moralitas agar peserta didik dapat menjalani hidup sesuai dengan norma yang dianut agama dan masyarakat. Dalam menentukan suatu pendekatan dan metode yang akan dipergunakan perlu mempunyai alasan dan landasan yang kuat dan faktor-faktor yang mendukung seperti karakteristik tujuan kegiatan dan karakteristik peserta didik.

Metode dalam membentuk kepribadian peserta didik melalui pendidikan moral dan karakter dapat dilakukan dengan berbagai sikap, seperti: keteladanan; penanaman atau penegakan kedisiplinan; pembiasaan; menciptakan suasana kondusif; integrasi dan internalisasi. Pengembangan dan pendidikan moral dalam membentuk kepribadian seseorang bertujuan untuk: melatih hidup tertib dan teratur; melatih sosialisasi; menanamkan toleransi dan sikap tenggang rasa; merangsang keberanian, tanggung jawab, sikap bangga dan bersyukur; melatih pengendalian emosi; melatih seseorang agar mampu menjaga dirinya sendiri; serta menanamkan sikap simpati, empati, gotong royong, menerima, dan menghargai. Pendidikan moral dan karakter merupakan aspek yang sangat penting karena menentukan ranah yang menentukan keberlangsungan suatu bangsa di benua manapun termasuk Indonesia, tapi pada praktiknya menerapkan pendidikan karakter tidak semudah membalikan telapak tangan. Maka harus ada sinergitas antara orang tua, guru, dan masyarakat demi terciptanya masyarakat madani yang barkarakter.

\section{DAFTAR RUJUKAN}

Andrianto, Tuhana Taufiq. Mengembangkan Karakter Sukses Anak di Era Cyber. Yogyakarta: Ar-Ruzz Media, 2011.

Azzet, Akhmad Muhaimin. Urgensi Pendidikan Karakter di Indonesia. Yogyakarta: ArRuzz Media, 2011. 
Djuwairiyah dan Moh. Nawafil, "Urgensi Pengelolaan Kelas: Suatu Analisis Filosofis dan Pemahaman Dasar Bagi Kalangan Pendidik di Pesantren", Edupedia: Jurnal Studi Pendidikan dan Pedagogi Islam, Vol. 5, No. 2, (Januari: 2021).

Elmubarok, Zaim. Membumikan Pendidikan Nilai. Bandung: Alfabeta, 2009.

Fitri, Agus Zaenul. Pendidikan Karakter Berbasis Nilai \& Etika di Sekolah. Yogyakarta: Ar-Ruzz Media, 2012.

Hamid, Hamdani, dan Beni Ahmadi Saebani. Pendidikan Karakter Perspektif Islam. Bandung: CV Pustaka Setia, 2013.

Hidayatullah, M. Furqon. Pendidikan Karakter: Membangun Peradaban Bangsa. Surakarta: Yuma Pustaka, 2010.

Machmud, Hadi. "Urgensi Pendidikan Moral dalam Membentuk Kepribadian Anak." Jurnal Al-Ta'dib 7, no. 2 (Juli 2014).

Maksudin. Pendidikan Karakter Non-Dikotomik. Yogyakarta: Pustaka Pelajar, 2013.

Muslich, Masnur. Pendidikan Karakter: Menjawab Tantangan Krisis Multidimensial. Jakarta: Bumi Aksara, 2014.

Nawafil, Moh. Cornerstone of Education: LandasanLandasan Pendidikan. Yogyakarta: Absolute Media, 2018.

Nawafil, Moh. dan Hafifuddin Nur, "Pendidikan Indigenous $\mathrm{Ala}$ Pesantren Untuk Memperkokoh Karakter Generasi Milenial", Edupedia: Jurnal Studi Pendidikan dan Pedagogi Islam, Vol. 5, No. 1, (Juli: 2020).

Saleh, Sirajuddin. "Peran Lembaga Pendidikan Dalam Membentuk Karakter Bangsa." Seminar Nasional: Pendidikan Ilmu-Imu Sosial Membentuk Karakter Bangsa Dalam Rangka Daya Saing Global, Kerjasama: Fakultas Ilmu Sosial UIN Makassar dan Himpunan Sarjana Pendidikan Ilmu-Imu Sosial Indonesia, Oktober 2016.

Suyadi. Strategi Pembelajaran Pendidikan Karakter. Bandung: PT Remaja Rosdakarya, 2013.

Zubaedi. Desain Pendidikan Karakter. Jakarta: Kencana Prenada Media Group, 2012. 